\title{
Investigation of Awareness and Anxiety Levels of Pregnant Women During Pandemic Process. A Multi-Centric Descriptive Cross-Sectional Survey Study in Istanbul, Turkey
}

\section{Rabia Merve Palalioglu ( $\sim$ drmerbiyik@gmail.com )}

University of Health Sciences, Umraniye Training and Research Hospital https://orcid.org/0000-0003-

2717-7925

\section{Ozan Karadeniz}

Istanbul Kanuni Sultan Suleyman Egitim ve Arastirma Hastanesi

Gokce Ipek Aytok

Umraniye EAH

\section{Batuhan Palalioglu}

Umraniye EAH

\section{Gizem Nur Koyan}

Istanbul Kanuni Sultan Suleyman Egitim ve Arastirma Hastanesi

\section{Halil Ibrahim Erbiyik}

Uskudar Universitesi

\section{Murat Muhcu}

Umraniye EAH

\section{Research Article}

Keywords: anxiety, awareness, COVID-19, pregnancy

Posted Date: November 24th, 2020

DOl: https://doi.org/10.21203/rs.3.rs-48034/v2

License: (c) (i) This work is licensed under a Creative Commons Attribution 4.0 International License.

Read Full License

Version of Record: A version of this preprint was published at Ginekologia Polska on January 31st, 2022. See the published version at https://doi.org/10.5603/GP.a2021.0087. 


\title{
Investigation of Awareness and Anxiety Levels of Pregnant Women During Pandemic Process
}

\author{
'A Multi-Centric Descriptive Cross-Sectional Survey Study in Istanbul, Turkey \\ University of Health Sciences Umraniye Training and Research Hospital, \\ University of Health Sciences Kanuni Sultan Suleyman Training and Research Hospital'
}

1. M.D. Rabia Merve Palalioglu, Department of Obstetrics and Gynecology, University of Health Sciences Umraniye Training and Research Hospital, Istanbul/Turkey, drmerbiyik@gmail.com, https://orcid.org/0000-0003-2717-7925

2. M.D. Ozan Karadeniz, Department of Obstetrics and Gynecology, University of Health Sciences Kanuni Sultan Suleyman Training and Research Hospital, Istanbul/Turkey, karoza08@gmail.com, https://orcid.org/0000-0002-2215-1198

3. M.D. Gokce Ipek Aytok, Department of Obstetrics and Gynecology, University of Health Sciences Umraniye Training and Research Hospital, Istanbul/Turkey, aytok.gokcemd@gmail.com, https://orcid.org/0000-0002-7583-0573

4. M.D. Batuhan Palalioglu, Department of Pediatrics, University of Health Sciences Umraniye Training and Research Hospital, Istanbul/Turkey, palalioglu@me.com, https://orcid.org/0000-0002-8861-399X

5. M.D. Gizem Nur Koyan, Department of Obstetrics and Gynecology, University of Health Sciences Kanuni Sultan Suleyman Training and Research Hospital, Istanbul/Turkey, gizkyn@gmail.com, https://orcid.org/0000-0003-1383-8905

6. M.D. Assistant Professor, Halil Ibrahim Erbiyik, 1. Operation Room Services, Uskudar University, 2. Dr. Moral Obstetrics and Gynecology Clinic, Istanbul/Turkey, drhalilibrahim@gmail.com, https://orcid.org/0000-0001-5526-2663

7. M.D. Associate Professor, Murat Muhcu, Department of Obstetrics and Gynecology, Maternal-Fetal Unit, University of Health Sciences Umraniye Training and Research Hospital, Istanbul/Turkey, muhcu@yahoo.com, https://orcid.org/0000-0001-7039-375X

Address for correspondence:

Rabia Merve Palalioglu, Department of Obstetrics and Gynecology, University of Health Sciences Umraniye Training and Research Hospital, Elmalikent Mh. Adem Yavuz Cd. No:1 Umraniye / Istanbul 34764 _ Turkey, Tel.+905336667627, E-mail: drmerbiyik@gmail.com

Key words: anxiety; awareness; COVID-19; pregnancy

Acknowledgements:

We thank Associate Professor Ibrahim Polat, for giving us the opportunity to conduct our survey in the emergency room and outpatient clinics of University of Health Sciences Istanbul Kanuni Sultan Suleyman Training and Research Hospital, Obstetrics and Gynecology Department.

Funding: Not applicable

Conflict of Interest: The authors declare that they have no conflict of interest. 


\title{
Investigation of Awareness and Anxiety Levels of Pregnant Women During \\ Pandemic Process
}

\begin{abstract}
Background:

COVID-19 pandemic is an important and urgent public health problem. It is currently unknown that how pregnant women deal with the Coronavirus disease and its results. The aim of this study is to evaluate the psychological impact of the coronavirus pandemic on pregnant women and to determine whether pregnant women have sufficient knowledge and awareness for a healthy antenatal process.

Methods: This prospective study was conducted at two centers. Regardless of the gestational age, a questionnaire was distributed to 1003 pregnant women in total, from 51 original questions that investigate the pregnant women's demographic data, history of contact with COVID-19-positive patients, knowledge and concerns about COVID19, precautions. 526 participants were included in the study. The questionnaire was delivered using the QR code method. The questionnaires were answered online by participants via SurveyMonkey in order to minimize contamination due to the pandemic.
\end{abstract}

Results: The period when anxiety was highest was the $2^{\text {nd }}$ trimester, whereas women in the $1^{\text {st }}$ trimester had the lowest level of anxiety. High levels of awareness were observed in patients with heart disease, but patients with diabetes mellitus had a high level of anxiety. There was a statistically significant correlation between anxiety and awareness scores of the coronavirus disease.

\section{Conclusion:}

It is important to maintain the mental and physical health of pregnant women, who are in a more delicate condition than other individuals in the society. In this regard, healthcare professionals have important duties such as taking necessary precautions and explaining the seriousness of the situation to pregnant women.

\section{INTRODUCTION}

The coronavirus disease (COVID-19) pandemic started on December 31, 2019, in the Chinese city of Wuhan, the capital of Hubei province [1]. On January 30, 2020, the World Health Organization reported that the COVID-19 outbreak was a public health emergency of international concern.

As of November 18,2020, the virus, which has rapidly spread across the country and around the world, has become a very serious issue and public health problem, with $56,237,909$ cases, 1,349,116 deaths, and 39,155,994 recovered cases in approximately 11 months.

In Turkey, the first case was reported on March 11, 2020, which was later than in other developing countries owing to the precautions taken prior to the emergence of the first case. As of November 18, 2020, 425,628 cases, 11,820 deaths, and 361,655 recovered cases have been reported in Turkey [2]. 
Pregnant women are known to be predisposed to the complications and the severe outcomes of a COVID-19 infection, as declared from SARS and MERS [3, 4].

The panic caused by the virus across the world coupled with the thought of staying home under quarantine, fear of death, protecting loved ones, and the mothering instinct has caused significant anxiety problems in particularly sensitive populations. While the effect of the pandemic on pregnant women is not yet known and only a few studies available. Royal College of Obstetrics and Gynecology reported that the COVID-19 pandemic increases the risk of perinatal anxiety, depression, and domestic violence [5]. The importance of mentally and emotionally supporting women has been emphasized in COVID-19 guidelines. Necessary measures should be taken to offer psychological support for pregnant women suffering from anxiety caused by this dramatic outbreak.

Pregnancy is related to increased risk for severe psychological issues such as depression, anxiety and postpartum psychosis due to physiological, immunological and hormonal alterations [6].

\section{MATERIALS AND METHODS}

This multi-centric prospective study, conducted between March 30 and May 30, 2020, was designed as a descriptive and cross-sectional study. The questionnaires were planned to be administered in the outpatient clinic for pregnant women and the obstetric emergency services at the Umraniye and Kanuni Sultan Suleyman Training and Research Hospitals.

The questionnaire was designed to identify awareness levels of COVID-19, identify anxiety levels in the admitted pregnant women, and evaluate their attitudes in terms of prevention measures.

The questionnaire comprises 51 original questions that investigate the pregnant women's demographic data, history of contact with COVID-19-positive patients, knowledge and concerns about COVID-19, precautionary measures, and approach to outbreak.

A link to the online questionnaire (SurveyMonkey) was sent to all pregnant participants, who were admitted to the obstetric outpatient clinics at Umraniye and Kanuni Sultan Suleyman Training Research Hospitals. The questionnaire was delivered using the QR code method and filled online to avoid contamination during this risky time.

The study was approved by the institutional ethics committee. Before starting the study, all volunteers received an informed consent form.

Questionnaires were distributed to a total of 1003 pregnant women aged 18-48 years who volunteered to participate in the survey study. Adolescent pregnant women and pregnant women with diagnosed depression, anxiety, and psychosis were excluded from the study. Illiterate pregnant women and pregnant women with diagnosed or suspected COVID-19 were not included in the study. 
529 of 1003 participants were included in the study, 526 of them answered all questions. Comparisons were made in terms of age, educational background, number of children, contact history, pregnancy week, risk factors, and anxiety and awareness levels.

According to responses to the 15 questions asked to measure anxiety regarding COVID-19 in pregnant women, based on the responses, we created a scoring system to determine the level of anxiety in pregnant women. Every correct response measuring anxiety was converted into a hundred-point scale for standardization and then assessed. Percentile values ranked at the 33.3 and is categorized as average, and anxiety was classified. (Table 3 )

According to the distribution of the responses given by the pregnant women to the 19 questions asked to assess their awareness of COVID-19, a scoring system of 19 questions to determine the level of awareness in pregnant women was created. Every correct answer indicating awareness was converted into a hundred-point scale for standardization. Percentile values ranked at the 33.3 and is categorized as average, and awareness was classified. (Table 4)

In order to assess the level of anxiety that commonly used in Turkey and can be applied easy which has been benefited from Beck Anxiety Scala [7].

\section{Statistical Analysis}

Power analysis was performed using the $G *$ Power (v3.1.7) program to determine the number of samples. The statistical analyses were performed using the Statistical Package for the Social Sciences, version 25 (SPSS Inc.). Along with the descriptive statistical methods for data analysis, the Shapiro-Wilk test and boxplot graphs were used to test the normality of variables in terms of normal distribution. Oneway ANOVA analysis of variance was used in intergroup comparisons of normally distributed variables, while the Bonferroni test was used to determine groups with differences. The Kruskal-Wallis test was used for intergroup comparisons of nonnormally distributed parameters, while Dunn's test was used to determine the groups with differences. The Mann-Whitney $U$ test was used to compare the parameters between two groups. $\mathrm{P}<0.05$ was considered statistically significant.

\section{RESULTS}

Distribution of demographic characteristics, distribution of Coronavirus (COVID-19) according to other characteristics, distribution of the answers given to the questions asked about the measuring the anxiety of pregnant women about Coronavirus (COVID-19) and distribution of the answers given to the questions asked about measuring the awareness of pregnant women about Coronavirus (COVID-19) are listed in Table 1-4, respectively.

According to the responses given to 19 questions asked to determine the level of awareness, the scores of awareness of COVID-19 were 5.26-100, with a mean score of $60.13 \pm 14.81$. Of the participants, $3.6 \%$ who scored 33.3 and below had low 
awareness, 58.7\% who scored 33.3-66.6 had moderate awareness, and 37.6\% who scored $\geq 67$ had high awareness. (Table 5)

In terms of number of children, however, there was a significant difference among the scores of COVID-19 awareness ( $<<0.05)$ : the awareness increased as the number of children increased. The awareness score of women who had no children was significantly lower than that of those who had three children $(p=0,016 ; p<0.05)$. There was a significant difference among the scores of COVID-19 awareness in terms of the number of people living in the household $(p<0.05)$; the awareness score of those with a household of 1-2 people was significantly lower than that of those with a household of 3-5 people ( $\mathrm{p}: 0,012 ; \mathrm{p}<0.05)$. There was a significant difference among the scores of COVID-19 awareness in terms of visiting the healthcare facility for routine pregnancy check-ups $(p<0.05)$; the awareness score of those continuing routine pregnancy check-ups was significantly higher than that of those not undergoing or occasionally undergoing routine pregnancy check-ups ( $\mathrm{p}: 0,001 ; \mathrm{p}<0.01)$. (Table 6)

The awareness score of patients with heart disease was significantly higher than that in those without heart disease $(p<0.05)$. (Table 7)

According to the responses given to 15 questions asked to determine the level of anxiety, the scores of COVID-19 anxiety ranged from 13.33 to 86.67 , with a mean score of $53.49 \pm 13.63$. Those with a score of $\leq 33.3$ were classified as having low anxiety and accounted for $11.4 \%$ of the respondents; those with scores of 33.3-66.6 had a moderate level of anxiety and accounted for $66.2 \%$ of the respondents, and those with a score of $\geq 67$ had a high level of anxiety and accounted for $22.4 \%$ of the respondents. (Table 8 )

In terms of contact with an individual with suspected COVID-19 in the past 14 days, there was a significant difference among the scores of COVID-19 anxiety ( $p<$ 0.05 ). It was found that those with a history of contact had significantly higher anxiety scores than those without a history of contact $(\mathrm{p}=0,014 ; \mathrm{p}<0.05)$. There was a significant difference among the scores of COVID-19 anxiety in terms of gestation week $(p<0.05)$, with the highest level of anxiety in the $2^{\text {nd }}$ trimester and lowest level of anxiety in the $1^{\text {st }}$ trimester $(\mathrm{p}=0,014 ; \mathrm{p}<0.05)$. There was a significant difference among the scores of COVID-19 anxiety in terms of visiting the healthcare institution for routine pregnancy check-ups $(\mathrm{p}<0.05)$. Those visiting regularly had significantly higher anxiety scores than those not visiting at all or visiting occasionally for routine pregnancy check-ups ( $p: 0,008 ; p<0.01$ ). (Table 9)

Those with DM had significantly higher anxiety scores than those without DM $(\mathrm{p}<0.05)$. (Table 10)

There was a statistically significant positive correlation between the scores of COVID-19 anxiety and the scores of COVID-19 awareness $(r=0,252 ; p=0,001$; $\mathrm{p}<0.01)$. As the awareness level of pregnant women increased, the anxiety level increased as well. (Fig. 1)

\section{DISCUSSION}


A total of 526 pregnant women from all three trimesters who were admitted to two centers in the Asian and European sides of Istanbul with the highest patient admissions were surveyed. Based on the data, $58.7 \%$ of the pregnant women were found to have moderate awareness. When the awareness rates of pregnant women with comorbidities were examined, it was found that the awareness levels of pregnant women with heart disease were higher. In total, $81.9 \%$ of the participants believed that they and their relatives were not sufficiently informed about COVID-19, and 59.1\% thought that healthcare workers did not inform them about the COVID-19 properly. In addition, $64.6 \%$ of the participants thought they needed information about COVID-19. These data suggest that the impact of COVID-19 on prenatal and postnatal periods is yet to be proven [8].

Although $58.7 \%$ of the pregnant women thought that the measures implemented by the Ministry of Health from the beginning of the pandemic in Turkey were satisfactory, only $18.1 \%$ thought that they were informed about how to protect and isolate themselves from the COVID-19 pandemic. These results are noteworthy and can encourage the Ministry of Health and healthcare workers to conduct more projects on informing people about the modes of transmission and protection against the virus.

While the COVID-19 awareness level is expected to increase as the level of education increases, there was no significant difference in the present study. This is consistent with the results obtained by Wang et al. According to their data, the anxiety rate was increased in patients with low educational background, whereas in our study, there was no positive correlation between educational background and anxiety [9].

Despite the fact that awareness levels increased as the number of children and the household size increased in the present study, there was no significant increase in the anxiety levels. In the study by Wang et al., a higher number of children and increased household size were not associated with increased awareness and anxiety [9]. Remarkably, based on data obtained in the current study, there was no significant difference between the awareness levels of healthcare worker women and nonhealthcare worker women. $40.9 \%$ of the pregnant women expressed hesitation to report infection with COVID-19 to their physician and the Ministry of Health. This indicates that almost $50 \%$ of the pregnant women suffering from the disease try to avoid quarantine and do not understand the gravity of the situation. The concealment of a diagnosis puts the person's immediate environment and public health and healthcare workers at risk. It can be concluded that during the management of this process, it is necessary to provide the necessary psychosocial support and increase awareness of the COVID-19 pandemic among the public.

In terms of both anxiety and awareness scoring, those who visited the healthcare institution regularly for routine pregnancy check-ups had high levels of awareness and high anxiety scores. In addition, there was a statistically significant correlation between the scores of COVID-19 anxiety and awareness.

In our study, $66.2 \%$ of the participants were moderately concerned, while Saccone et al. found that $53 \%$ of respondents had been psychologically affected at a high level [10]. 
In terms of comorbidities, those with DM were more concerned about getting infected by the virus, while patients with cancer and patients with chronic lung disease, who are thought to be more prone to stress and depression, did not have a significantly increased anxiety.

The period when anxiety was observed at the highest level was the $2^{\text {nd }}$ trimester, whereas the lowest level was seen in the $1^{\text {st }}$ trimester. On the contrary, in the study by Tang et al [11], the anxiety levels of pregnant women in the $1^{\text {st }}$ trimester were higher.

The study by Durankuş and Aksu included 260 participants, and the study by Yassa et al. included 172 participants. Both reported negative psychological effects of COVID-19 on pregnant women [12, 13]. In the present study, $44.7 \%$ of the participants from all trimesters thought that physicians could not diagnose COVID-19 in a timely manner and treat COVID-19 properly, while only $7.5 \%$ of participants thought so in the study by Yassa et al. [13].

In the present study, $47 \%$ of participants thought that social media was not being used efficiently for informing the society. Wu Y et al. reported apart from the benefits of social media, it causes extreme fear, isolation, fear of death, and proneness to depression among the society, especially during the time of lockdown [14].

Mirzadeh and Khedmat particularly stressed that pregnant women need psychological support during this crisis [15].

Previous studies showed that there is an increased predisposition to emotional state disorders in pregnancy and childhood [16, 17, 18]. Pregnant women experience more anxiety and suffer from fears that arise as the delivery date approaches during advanced gestation weeks [16]. It is also obvious that if the concerns that pregnant women suffering from infectious diseases have about the health of their babies are added to this, their mental health can be affected even more.

During the pandemic, women are under stress and may therefore complain about a large number of psychological symptoms or nonspecific symptoms that can be confused with those of COVID-19. They can also face many problems, such as emergence of unintended pregnancies.

In the present study, for example, it is noteworthy that $39 \%$ of the pregnant women avoided visiting the healthcare institution for routine pregnancy check-ups.

According to all these results, healthcare workers should further inform pregnant women about COVID-19.

\section{LIMITATIONS}

A significant number of individuals who had been followed up or treated as outpatients or inpatients for confirmed or suspected cases of COVID-19 could not be surveyed as part of the present study since our hospital served as a major hospital during this pandemic. The duration of the study was prolonged to reach the targeted number of pregnant women due to the decrease in the number of patients admitted to outpatient clinics due to fear and anxiety. Patients who had difficulty reading and understanding Turkish were not surveyed to avoid incorrect results. Owing to the high number of questions asked, some of the patients filled out the questionnaire by skipping some of 
the questions and some were unable to complete the questionnaire. Of all the pregnant women admitted to the emergency service, those who needed urgent diagnosis and treatment were not surveyed. Due to socioeconomic reasons such as not having access to internet or phone, some pregnant women could not be surveyed online.

\section{CONCLUSIONS}

This study shows that pregnant women have insufficient knowledge about this important health problem, their anxiety is high and their awareness is insufficient.

Healthcare workers have an important duty to ensure early identification of the negative outcomes that may arise due to COVID-19 in pregnant women so that pregnant women are provided with the necessary psychological support.

This study presents significant clues that might constitute a ground for future studies. In addition, this study offers guidance for family physicians, obstetricians, midwives, and other healthcare workers for developing measures to protect maternal and newborn health at an advanced level.

\section{DECLARATIONS}

Funding: Not applicable

Conflict of Interest: The authors declare that they have no conflict of interest.

Ethics approval: All procedures performed in studies involving human participants were in accordance with the ethical standards of the institutional research committee (The ethics committee of University of Health Sciences Umraniye Training and Research Hospital, date: April 14, 2020; approval number: B.10.1.TKH.4.34.H.GP.0.01/84-15/04/2020-54132726-000-8582/00116578941) and with the 1964 Helsinki declaration and its later amendments or comparable ethical standards. Our scientific research application No. 15916306-604.01.01 was approved by Istanbul Provincial Health Directorate and No. 2020-05-04T23_03_03 was approved by the Ministry of Health of the Republic of Turkey.

Informed consent: Informed consent was obtained from all individual participants included in the study.

Consent for publication: Patients signed informed consent regarding publishing their data.

This article does not contain any studies with animals performed by any of the authors.

\section{REFERENCES}

1. Huang C, Wang Y, Li X, Ren L, Zhao J, Hu Y, Zhang L, Fan G, Xu J, Gu X, Cheng Z, Yu T, Xia J, Wei Y, Wu W, Xie X, Yin W, Li H, Liu M, Xiao Y, Gao H, Guo L, Xie J, Wang G, Jiang R, Gao Z, Jin Q, Wang J, Cao B. (2020). Clinical features of patients infected with 2019 novel coronavirus in Wuhan, China. Lancet. Feb 15;395(10223):497-506. doi: 10.1016/S0140-6736(20)30183-5. Epub 2020 Jan 24. Erratum in: Lancet. 2020 Jan 30;: PMID: 31986264 ; PMCID: PMC7159299. 
2. Worldometer, COVID-19 Coronavirus Pandemic, Last updated: November 18, 2020, https://www.worldometers.info/coronavirus

3. Di Mascio D, Khalil A, Saccone G, Rizzo G, Buca D, Liberati M, Vecchiet J, Nappi L, Scambia G, Berghella V, D'Antonio F. (2020). Outcome of coronavirus spectrum infections (SARS, MERS, COVID-19) during pregnancy: a systematic review and meta-analysis. Am J Obstet Gynecol MFM. 2020 May;2(2):100107. doi: 10.1016/j.ajogmf.2020.100107. Epub 2020 Mar 25. PMID: 32292902; PMCID: PMC7104131.

4. Schwartz DA, Graham AL. (2020). Potential Maternal and Infant Outcomes from (Wuhan) Coronavirus 2019-nCoV Infecting Pregnant Women: Lessons from SARS, MERS, and Other Human Coronavirus Infections. Viruses. 2020 Feb 10;12(2):194. doi: 10.3390/v12020194. PMID: 32050635; PMCID: PMC7077337.

5. The Royal College of Obstetricians and Gynaecologists (RCOG). (2020). Coronavirus (COVID-19) Infection in Pregnancy Information for healthcare professionals Version 6: Published Friday 3 April 2020 Available from: https://www.rcog.org.uk/globalassets/documents/guidelines/2020-04-03-coronaviruscovid-19-infection-in-pregnancy.pdf

6. Kourtis AP, Read JS, Jamieson DJ. (2014). Pregnancy and infection. N Engl J Med. 2014 Jun 5;370(23):2211-8. doi: 10.1056/NEJMra1213566. PMID: 24897084; PMCID: PMC4459512.

7. Beck AT, Epstein N, Brown G, Steer RA. (1988). An inventory for measuring clinical anxiety: psychometric properties. Journal of Consulting and Clinical Psychology. 1988 Dec;56(6):893-897. DOI: 10.1037//0022-006x.56.6.893.

8. Chen H, Guo J, Wang C, Luo F, Yu X, Zhang W, Li J, Zhao D, Xu D, Gong Q, Liao J, Yang H, Hou W, Zhang Y. (2020). Clinical characteristics and intrauterine vertical transmission potential of COVID-19 infection in nine pregnant women: a retrospective review of medical records. Lancet. 2020 Mar 7;395(10226):809-815. doi: 10.1016/S0140-6736(20)30360-3. Epub 2020 Feb 12. Erratum in: Lancet. $2020 \mathrm{Mar}$ 28;395(10229):1038. Erratum in: Lancet. 2020 Mar 28;395(10229):1038. PMID: 32151335; PMCID: PMC7159281.

9. Wang C, Pan R, Wan X, Tan Y, Xu L, Ho CS, Ho RC. (2020). Immediate Psychological Responses and Associated Factors during the Initial Stage of the 2019 Coronavirus Disease (COVID-19) Epidemic among the General Population in China. Int J Environ Res Public Health. 2020 Mar 6;17(5):1729. doi: 10.3390/ijerph17051729. PMID: 32155789; PMCID: PMC7084952.

10. Saccone G, Florio A, Aiello F, Venturella R, De Angelis MC, Locci M, Bifulco G, Zullo F, Di Spiezio Sardo A. (2020). Psychological impact of coronavirus disease 2019 in pregnant women. Am J Obstet Gynecol. 2020 Aug;223(2):293-295. doi: 10.1016/j.ajog.2020.05.003. Epub 2020 May 7. PMID: 32387321; PMCID: PMC7204688.

11. Tang PL, Wang HH, Chou FH. (2015). A Systematic Review and Meta-Analysis of Demoralization and Depression in Patients With Cancer. Psychosomatics. 2015 Nov-Dec;56(6):634-43. doi: 10.1016/j.psym.2015.06.005. Epub 2015 Jun 19. PMID: 26411374. 
12. Durankuş F, Aksu E. (2020). Effects of the COVID-19 pandemic on anxiety and depressive symptoms in pregnant women: a preliminary study. J Matern Fetal Neonatal Med. 2020 May 18:1-7. doi: 10.1080/14767058.2020.1763946. Epub ahead of print. PMID: 32419558.

13. Yassa M, Birol P, Yirmibes C, Usta C, Haydar A, Yassa A, Sandal K, Tekin AB, Tug N. (2020). Near-term pregnant women's attitude toward, concern about and knowledge of the COVID-19 pandemic. J Matern Fetal Neonatal Med. 2020 Nov;33(22):3827-3834. doi: 10.1080/14767058.2020.1763947. Epub 2020 May 19. PMID: 32429780 .

14. Wu Y, Zhang C, Liu H, Duan C, Li C, Fan J, Li H, Chen L, Xu H, Li X, Guo Y, Wang Y, Li X, Li J, Zhang T, You Y, Li H, Yang S, Tao X, Xu Y, Lao H, Wen M, Zhou Y, Wang J, Chen Y, Meng D, Zhai J, Ye Y, Zhong Q, Yang X, Zhang D, Zhang J, Wu X, Chen W, Dennis CL, Huang HF. (2020). Perinatal depressive and anxiety symptoms of pregnant women during the coronavirus disease 2019 outbreak in China. Am J Obstet Gynecol. 2020 Aug;223(2):240.e1-240.e9. doi: 10.1016/j.ajog.2020.05.009. Epub 2020 May 11. PMID: 32437665; PMCID: PMC7211756.

15. Mirzadeh M, Khedmat L. (2020). Pregnant women in the exposure to COVID-19 infection outbreak: the unseen risk factors and preventive healthcare patterns. J Matern Fetal Neonatal Med. 2020 Apr 7:1-2. doi: 10.1080/14767058.2020.1749257. Epub ahead of print. PMID: 32223477.

16. Zar M, Wijma K, Wijma B. (2002). Relations between anxiety disorders and fear of childbirth during late pregnancy. Clin Psychol Psychother, 9(2):122-130. https://doi.org/10.1002/cpp.305.

17. Gambina I, Soldera G, Benevento B, Trivellato P, Visentin S, Cavallin F, Trevisanuto D \& Zanardo V. (2011). Postpartum psychosocial distress and late preterm delivery, Journal of Reproductive and Infant Psychology, 29:5, 472-479, DOI: 10.1080/02646838.2011.653962.

18. Holditch-Davis D, Santos H, Levy J, White-Traut R, O'Shea TM, Geraldo V, David R. (2015). Patterns of psychological distress in mothers of preterm infants. Infant Behav Dev. 2015 Nov;41:154-63. doi: 10.1016/j.infbeh.2015.10.004. Epub 2015 Oct 22. PMID: 26495909; PMCID: PMC4654120.

\section{Figure Caption}

Fig. 1

Relationship between COVID-19's anxiety scores and awareness scores on pregnant women

\section{Table Captions}


Table 1

Table 2

Table 3

Table 4

Table 5

Table 6

Table 7

Table 8

Table 9

Table 10
Distribution of demographic characteristics

Distribution of Coronavirus (COVID-19) according to other characteristics

Distribution of the answers given to the questions asked about the measuring the anxiety of pregnant women about Coronavirus (COVID-19)

Distribution of the answers given to the questions asked about measuring the awareness of pregnant women about Coronavirus (COVID-19)

Distribution of COVID-19 Awareness Scores

Evaluations based on COVID-19 Awareness Scores

Evaluation of COVID-19 Awareness Scores according to the risk factors of pregnant women

Distribution of COVID-19 Anxiety Scores

Evaluations based on COVID-19 Anxiety Scores

Evaluation of COVID-19 Anxiety Scores according to the risk factors of pregnant women

Fig. 1

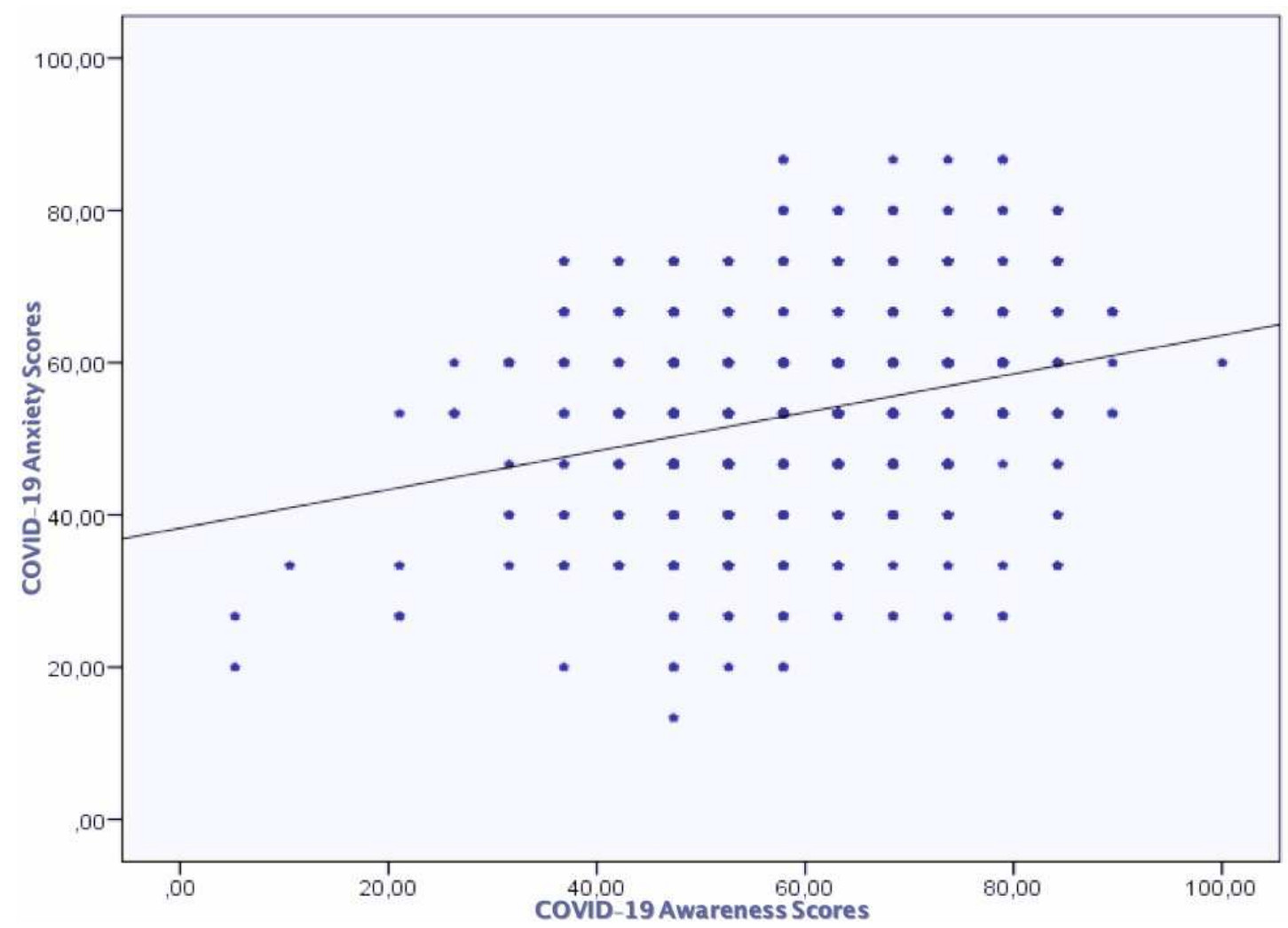

Relationship between COVID-19's anxiety scores and awareness scores on pregnant women 
Table 1: Distribution of demographic characteristics

\begin{tabular}{|c|c|c|c|}
\hline & & $\mathbf{n}$ & $\%$ \\
\hline \multirow[t]{2}{*}{ Health-care worker (n:416) } & Yes & 29 & $7.0 \%$ \\
\hline & No & 387 & $93,0 \%$ \\
\hline \multirow[t]{4}{*}{ How many children? } & None & 241 & $45,8 \%$ \\
\hline & 1 & 172 & $32,7 \%$ \\
\hline & 2 & 67 & $12,7 \%$ \\
\hline & $3 \leq$ & 46 & $8,7 \%$ \\
\hline \multirow[t]{3}{*}{ Marital status } & Married & 513 & $97,5 \%$ \\
\hline & Single & 9 & $1,7 \%$ \\
\hline & Widowed/Divorced & 4 & $0,8 \%$ \\
\hline \multirow[t]{5}{*}{ Educational status } & Primary school & 74 & $14,1 \%$ \\
\hline & Middle school & 94 & $17,9 \%$ \\
\hline & High school & 130 & $24,7 \%$ \\
\hline & Associate's degree & 67 & $12,7 \%$ \\
\hline & Postgraduate and more & 161 & $30,6 \%$ \\
\hline \multirow[t]{4}{*}{ Do you smoke? } & Never & 459 & $87,3 \%$ \\
\hline & Less than 10 cigarettes & 45 & $8,6 \%$ \\
\hline & 10 to 20 cigarettes & 18 & $3,4 \%$ \\
\hline & $\begin{array}{l}\text { More than } 20 \\
\text { cigarettes }\end{array}$ & 4 & $0,8 \%$ \\
\hline \multirow[t]{3}{*}{ Gestational age } & $<14$ weeks & 123 & $23,8 \%$ \\
\hline & 14-28 weeks & 152 & $29,5 \%$ \\
\hline & $>28$ weeks & 241 & $46,7 \%$ \\
\hline \multirow{3}{*}{$\begin{array}{l}\text { How many people do live in your } \\
\text { house? }\end{array}$} & $1-2$ & 226 & $43,0 \%$ \\
\hline & 3 to 5 & 262 & $49,8 \%$ \\
\hline & 6 or more & 38 & $7,2 \%$ \\
\hline \multirow{3}{*}{$\begin{array}{l}\text { How many times have you been to } \\
\text { the Emergency Room in the last } \\
\text { year? }\end{array}$} & Never & 187 & $36,3 \%$ \\
\hline & 1 to 5 times & 253 & $49,1 \%$ \\
\hline & More than 5 times & 75 & $14,6 \%$ \\
\hline \multirow{3}{*}{$\begin{array}{l}\text { Have you exposed to a person who } \\
\text { is suspected of Coronavirus } \\
\text { (COVID-19) infection? }\end{array}$} & No & 500 & $95,1 \%$ \\
\hline & Yes & 8 & $1,5 \%$ \\
\hline & Not sure & 18 & $3,4 \%$ \\
\hline \multirow{2}{*}{$\begin{array}{l}\text { Have you ever used public } \\
\text { transportation in the last month? }\end{array}$} & Yes & 121 & $23,0 \%$ \\
\hline & No & 405 & $77,0 \%$ \\
\hline \multirow{3}{*}{$\begin{array}{l}\text { How many times do you touch your } \\
\text { face in a daytime? }\end{array}$} & Never & 55 & $10,5 \%$ \\
\hline & 1 to 5 times & 258 & $49,0 \%$ \\
\hline & More than 5 times & 213 & $40,5 \%$ \\
\hline \multirow{3}{*}{$\begin{array}{l}\text { Do you go to the hospital for your } \\
\text { routine prenatal visits? }\end{array}$} & No. I don't go. & 106 & $20,2 \%$ \\
\hline & Sometimes, I go. & 99 & $18,8 \%$ \\
\hline & Regularly, I go. & 321 & $61,0 \%$ \\
\hline \multicolumn{4}{|c|}{ Which risk factors do you have related to Coronavirus (Covid-19) infection? } \\
\hline & Diabetes & 16 & $3,0 \%$ \\
\hline & Hypertension & 12 & $2,3 \%$ \\
\hline
\end{tabular}




$\begin{array}{lll}\text { Lung Diseases } & 28 & 5,3 \% \\ \text { Cancer } & 7 & 1,3 \% \\ \text { Heart Diseases } & 21 & 4,0 \% \\ \text { Liver Diseases } & 8 & 1,5 \% \\ \text { Renal Diseases } & 6 & 1,1 \% \\ \text { Thyroid Diseases } & 20 & 3,8 \% \\ \text { Other Risk Factors } & 15 & 2,9 \% \\ \text { None } & 420 & 79,8 \%\end{array}$

Table 2: Distribution of Coronavirus (COVID-19) according to other characteristics

\begin{tabular}{|c|c|c|c|}
\hline & & $\mathrm{n}$ & $\%$ \\
\hline \multirow{3}{*}{$\begin{array}{l}\text { Do you think that antibiotics are effective } \\
\text { against Coronavirus (COVID-19)? }\end{array}$} & No & 321 & $61,0 \%$ \\
\hline & Not sure & 159 & $30,2 \%$ \\
\hline & Yes & 46 & $8,7 \%$ \\
\hline \multirow{3}{*}{$\begin{array}{l}\text { Do you think that social media is taken } \\
\text { advantage for giving information about the } \\
\text { Coronavirus (Covid-19) infection? }\end{array}$} & No & 126 & $24,0 \%$ \\
\hline & Not sure & 121 & $23,0 \%$ \\
\hline & Yes & 279 & $53,0 \%$ \\
\hline \multirow{3}{*}{$\begin{array}{l}\text { Have you ever get vaccinated against } \\
\text { influenza? }\end{array}$} & No & 449 & $85,4 \%$ \\
\hline & I don't remember & 51 & $9,7 \%$ \\
\hline & Yes & 26 & $4,9 \%$ \\
\hline
\end{tabular}

Table 3: Distribution of the answers given to the questions asked about the measuring the anxiety of pregnant women about Coronavirus (COVID-19)

\begin{tabular}{|c|c|c|c|}
\hline & & $\mathbf{n}$ & $\%$ \\
\hline \multirow{3}{*}{$\begin{array}{l}\text { Do you think that you are vulnerable to Coronavirus } \\
\text { (Covid-19) because you are pregnant? }\end{array}$} & No & 195 & $37,1 \%$ \\
\hline & Not sure & 138 & $26,2 \%$ \\
\hline & Yes & 193 & $36,7 \%$ \\
\hline \multirow{3}{*}{$\begin{array}{l}\text { Do you think that mother-to-child transmission of } \\
\text { Coronavirus (Covid-19) infection is possible during } \\
\text { pregnancy? }\end{array}$} & Not sure & 200 & $38,0 \%$ \\
\hline & No & 163 & $31,0 \%$ \\
\hline & Yes & 163 & $31,0 \%$ \\
\hline \multirow{3}{*}{$\begin{array}{l}\text { Do you think that Coronavirus (Covid-19) can transmit } \\
\text { through breastmilk or breastfeeding? }\end{array}$} & Not sure & 210 & $39,9 \%$ \\
\hline & No & 131 & $24,9 \%$ \\
\hline & Yes & 185 & $35,2 \%$ \\
\hline \multicolumn{4}{|c|}{$\begin{array}{l}\text { Which of the following do you think that could happen to you because of the anxiety of getting infected by } \\
\text { Coronavirus (Covid-19)? }\end{array}$} \\
\hline & Labor pain & 77 & $14,6 \%$ \\
\hline & Bleeding & 38 & $7,2 \%$ \\
\hline & Water break & 22 & $4,2 \%$ \\
\hline & Preterm labor & 78 & $14,8 \%$ \\
\hline & Abortus/Stillbirth & 69 & $13,1 \%$ \\
\hline & None & 315 & $59,9 \%$ \\
\hline
\end{tabular}


Do you take vitamins to boost your immune system against Coronavirus (COVID-19) infection?

\begin{tabular}{lll}
\hline No. I don't. & $\mathbf{2 6 9}$ & $\mathbf{5 1 , 1 \%}$ \\
Sometimes, I do. & 103 & $19,6 \%$ \\
Regularly, I do. & 154 & $29,3 \%$ \\
\hline I am not anxious & 47 & $8,9 \%$ \\
I am a little bit anxious & 120 & $22,8 \%$ \\
I am anxious & $\mathbf{2 0 8}$ & $\mathbf{3 9 , 5 \%}$ \\
I am very anxious & $\mathbf{1 5 1}$ & $\mathbf{2 8 , 7 \%}$ \\
\hline
\end{tabular}

Does the thought of getting infected by Coronavirus (COVID-19) cause any of the followings?

\begin{tabular}{|c|c|c|c|}
\hline & Numbness/Tingling & 19 & $3,6 \%$ \\
\hline & Hot flushes & 74 & $14,1 \%$ \\
\hline & Weakness/Shivering & 43 & $8,2 \%$ \\
\hline & $\begin{array}{l}\text { The idea of something bad is } \\
\text { going to happen }\end{array}$ & 161 & $30,6 \%$ \\
\hline & Tachycardia & 56 & $10,6 \%$ \\
\hline & Dizziness & 18 & $3,4 \%$ \\
\hline & Feeling like drowning & 55 & $10,5 \%$ \\
\hline & Feeling like you can't breathe & 73 & $13,9 \%$ \\
\hline & Fear of death & 87 & $16,5 \%$ \\
\hline & Stomach pain & 63 & $12,0 \%$ \\
\hline & No. I don't feel any of them. & 171 & $32,5 \%$ \\
\hline \multirow[t]{4}{*}{$\begin{array}{l}\text { If you had get infected by the Coronavirus (COVID-19), } \\
\text { what is your possibility of getting well? }\end{array}$} & $\begin{array}{l}\text { I don't think that I could get } \\
\text { well. }\end{array}$ & 92 & $17,5 \%$ \\
\hline & $\begin{array}{l}\text { I am not sure that I could get } \\
\text { well. }\end{array}$ & 148 & $28,1 \%$ \\
\hline & I may get well. & 225 & $42,8 \%$ \\
\hline & I would definitely get well. & 61 & $11,6 \%$ \\
\hline \multirow{3}{*}{$\begin{array}{l}\text { Do you think that the doctors can make the right } \\
\text { diagnosis of Coronavirus (COVID-19) infection and then } \\
\text { treat you in the right way? }\end{array}$} & No & 39 & $7,4 \%$ \\
\hline & Not sure & 196 & $37,3 \%$ \\
\hline & Yes & 291 & $55,3 \%$ \\
\hline \multirow{3}{*}{$\begin{array}{l}\text { Do you think of terminating your pregnancy because of } \\
\text { the risk of mother-to-child transmission of Coronavirus } \\
\text { (COVID-19) infection? }\end{array}$} & No & 467 & $88,8 \%$ \\
\hline & Not sure & 46 & $8,7 \%$ \\
\hline & Yes & 13 & $2,5 \%$ \\
\hline \multirow{3}{*}{$\begin{array}{l}\text { Do you think that you wash your hands after coughing, } \\
\text { sneezing or touching your nose more frequently than } \\
\text { before the Coronavirus (COVID-19) pandemic started? }\end{array}$} & No & 35 & $6,7 \%$ \\
\hline & Not sure & 79 & $15,0 \%$ \\
\hline & Yes & 412 & $78,3 \%$ \\
\hline \multirow{3}{*}{$\begin{array}{l}\text { Do you avoid going out because of the Coronavirus } \\
\text { (COVID-19) pandemic? }\end{array}$} & No & 30 & $6,1 \%$ \\
\hline & Sometimes & 0 & $0,0 \%$ \\
\hline & Yes & 460 & $93,9 \%$ \\
\hline \multirow{4}{*}{$\begin{array}{l}\text { What would you do if a doctor advised a treatment at } \\
\text { home to your housemate due to the Coronavirus } \\
\text { (COVID-19) infection? (n: } 283 \text { ) }\end{array}$} & I do nothing. & 4 & $1,4 \%$ \\
\hline & $\begin{array}{l}\text { I would take the precautions like } \\
\text { putting on a mask, wearing } \\
\text { gloves, etc. and I would continue } \\
\text { to live in the same house. }\end{array}$ & 54 & $19,1 \%$ \\
\hline & $\begin{array}{l}\text { I would live in another room in } \\
\text { the house. }\end{array}$ & 165 & $58,3 \%$ \\
\hline & I would move to another house. & 60 & $21,2 \%$ \\
\hline \multirow{2}{*}{$\begin{array}{l}\text { What would you do if your doctor advised you to get } \\
\text { tested for Coronavirus (COVID-19) after exposure to a }\end{array}$} & I would refuse & 37 & $13,0 \%$ \\
\hline & I am not sure about it & 82 & $28,8 \%$ \\
\hline
\end{tabular}


person who is suspected of having Coronavirus (COVID- I would accept

19) infection? (n: 285)

\begin{tabular}{|c|c|c|c|}
\hline \multirow{6}{*}{$\begin{array}{l}\text { If you thought that you had some of the signs/symptoms of } \\
\text { Coronavirus (COVID-19) infection, what would you do? } \\
\text { (n: 282) }\end{array}$} & $\begin{array}{l}\text { I would immediately go to a } \\
\text { hospital }\end{array}$ & 148 & $52,5 \%$ \\
\hline & $\begin{array}{l}\text { I would observe the } \\
\text { signs/symptoms and wouldn't } \\
\text { go to the hospital unless I get } \\
\text { worse }\end{array}$ & 24 & $8,5 \%$ \\
\hline & $\begin{array}{l}\text { I would call my healthcare } \\
\text { professional friends and } \\
\text { consult about going to the } \\
\text { hospital }\end{array}$ & 20 & $7,1 \%$ \\
\hline & $\begin{array}{l}\text { I would call } 184 \text { and consult } \\
\text { the Ministry of Health }\end{array}$ & 64 & $22,7 \%$ \\
\hline & $\begin{array}{l}\text { I would not go to a hospital } \\
\text { and quarantine myself at } \\
\text { home }\end{array}$ & 14 & $5,0 \%$ \\
\hline & $\begin{array}{l}\text { I don't think that I should do } \\
\text { something about it }\end{array}$ & 12 & $4,3 \%$ \\
\hline
\end{tabular}

Table 4: Distribution of the answers given to the questions asked about measuring the awareness of pregnant women about Coronavirus (COVID-19)

\begin{tabular}{|c|c|c|c|}
\hline \multirow{4}{*}{$\begin{array}{l}\text { Do you think that you have enough information } \\
\text { about the transmission route of Coronavirus } \\
\text { (Covid-19) infection? }\end{array}$} & & \multirow{2}{*}{$\frac{\mathbf{n}}{57}$} & \multirow{2}{*}{$\frac{\%}{10,8 \%}$} \\
\hline & No & & \\
\hline & Not sure & 62 & $11,8 \%$ \\
\hline & Yes & 407 & $77,4 \%$ \\
\hline \multirow{3}{*}{$\begin{array}{l}\text { Do you think that you have enough information } \\
\text { about the signs/symptoms of Coronavirus } \\
\text { (Covid-19) infection? }\end{array}$} & No & 51 & $9,7 \%$ \\
\hline & Not sure & 68 & $12,9 \%$ \\
\hline & Yes & 407 & $77,4 \%$ \\
\hline \multicolumn{4}{|l|}{$\begin{array}{l}\text { What are the most important signs/symptoms of } \\
\text { Coronavirus (Covid-19) infection in your opinion? }\end{array}$} \\
\hline & High fever & 453 & $86,1 \%$ \\
\hline & Cough & 329 & $62,5 \%$ \\
\hline & Shortness of breath & 372 & $70,7 \%$ \\
\hline & Other & 32 & $6,1 \%$ \\
\hline \multirow{3}{*}{$\begin{array}{l}\text { Would you get vaccinated with Coronavirus } \\
\text { (Covid-19) vaccine? }\end{array}$} & No & 66 & $12,5 \%$ \\
\hline & Not sure & 164 & $31,2 \%$ \\
\hline & Yes & 296 & $56,3 \%$ \\
\hline \multirow{3}{*}{$\begin{array}{l}\text { Do you think that you and your family get well- } \\
\text { informed about Coronavirus (Covid-19) } \\
\text { infection? }\end{array}$} & No & 94 & $17,9 \%$ \\
\hline & Not sure & 337 & $64,1 \%$ \\
\hline & Yes & 95 & $18,1 \%$ \\
\hline \multirow{3}{*}{$\begin{array}{l}\text { Do you think that Coronavirus (Covid-19) } \\
\text { infection is preventable? }\end{array}$} & No & 43 & $8,2 \%$ \\
\hline & Not sure & 127 & $24,1 \%$ \\
\hline & Yes & 356 & $67,7 \%$ \\
\hline \multirow{4}{*}{$\begin{array}{l}\text { Do you think that Coronavirus (COVID-19) } \\
\text { infection is lethal? }\end{array}$} & No & 34 & $6,5 \%$ \\
\hline & Not sure & 69 & $13,1 \%$ \\
\hline & Yes & 423 & $80,4 \%$ \\
\hline & No & 114 & $21,7 \%$ \\
\hline
\end{tabular}


Do you think that the precautions that the

of Health take against Coronavirus

Not sure (Covid-19) are sufficient?

Have you ever get informed about Coronavirus $\mathrm{N}$

(Covid-19) infection by the healthcare professionals?

I don't remember

Do you try to protect yourself from getting

infected by Coronavirus (COVID-19)

and if you do, what do you do for it?

Yes

$311 \quad 59,1 \%$

$41 \quad 7,8 \%$

$17433,1 \%$

Which of the following can provide reducing the number of new Coronavirus (COVID-19) cases and deaths from this infection in Turkey?
Washing hands frequently

Handsanitizer/Cologne

Staying away from crowded places

Mask

Gloves

Staying at home

Other

None

Good personal hygiene

5

The precautions that the Ministry of

Health takes

Healthy eating habits/Good genetics

Staying at home except for essential needs

None

All

Would you quarantine yourself at home for 14
days if you exposed to a person who is infected
with Coronavirus (COVID-19)?

Would you see a friend/relative in 14 days since
he/she came from a foreign country?

No

Not sure

Yes

No

Not sure

Yes

Do you follow the daily news about the

Coronavirus (COVID-19) in Turkey and worldwide?

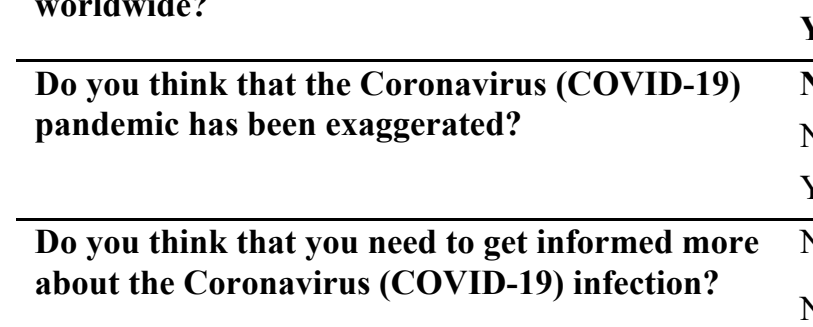

No

Yes

No

Not sure

Yes

No

Not sure
Sometimes

Yes

What would you do if your doctor advised you hospitalization due to the Coronavirus (COVID19) infection? (n:283)

What would you do if your doctor advised you to get tested for Coronavirus (COVID-19) after exposure to a person who is diagnosed with Coronavirus (COVID-19) infection? (n:282)
I would not accept the treatment.

I am not sure about it.

I would accept the treatment.

I would refuse.

I am not sure about it.

I would accept.

I wouldn't share it with anyone.

$85 \quad 16,2 \%$

$16 \quad 3,0 \%$

$18 \quad 3,4 \%$

$492 \quad 93,5 \%$

$507 \quad 96,4 \%$

$14 \quad 2,7 \%$

$5 \quad 1,0 \%$

$16 \quad 3,0 \%$

$53 \quad 10,1 \%$

$457 \quad 86,9 \%$

$326 \quad 62,0 \%$

$70 \quad 13,3 \%$

$130 \quad 24,7 \%$

$186 \quad 35,4 \%$

$71 \quad 13,5 \%$

$26951,1 \%$

$21 \quad 7,4 \%$

$39 \quad 13,8 \%$

$223 \quad 78,8 \%$

$2910,3 \%$

$57 \quad 20,2 \%$

$196 \quad 69,5 \%$

$18 \quad 6,3 \%$




\begin{tabular}{llll}
\hline $\begin{array}{l}\text { Who would you share it with if you were } \\
\text { diagnosed with Coronavirus (COVID-19) } \\
\text { infection? (n:286) }\end{array}$ & I would share it only with my spouse. & 53 & $18,5 \%$ \\
& $\begin{array}{l}\text { I would share it with my first degree } \\
\text { relatives and friends. }\end{array}$ & 46 & $16,1 \%$ \\
& $\begin{array}{l}\text { I would share it with the doctors who are } \\
\text { following me for pregnancy. }\end{array}$ & 47 & $16,4 \%$ \\
& I would share with everybody. & $\mathbf{1 2 2}$ & $\mathbf{4 2 , 7 \%}$ \\
\hline
\end{tabular}

Table 5: Distribution of COVID-19 Awareness Scores

COVID-19 Awareness Scores

\begin{tabular}{lc}
\hline \hline Min-Max & $5,26-100$ \\
Avr \pm SD & $60,13 \pm 14,81$ \\
\hline Low Awareness Levels & $19(3,6)$ \\
\hline Moderate Awareness Levels & $309(58,7)$ \\
\hline High Awareness Levels & $198(37,6)$ \\
\hline
\end{tabular}

Table 6: Evaluations based on COVID-19 Awareness Scores

\begin{tabular}{|c|c|c|c|c|c|}
\hline & & \multicolumn{3}{|c|}{$\begin{array}{c}\text { COVID-19 Awareness } \\
\text { Scores }\end{array}$} & \multirow[b]{2}{*}{$\mathbf{p}$} \\
\hline & & Average & SD & Median & \\
\hline \multirow[t]{5}{*}{ Educational Status } & Primary School & 60,88 & 17,73 & 63,16 & ${ }^{a} 0,152$ \\
\hline & Middle School & 63,38 & 14,76 & 63,16 & \\
\hline & High School & 59,72 & 16,64 & 57,89 & \\
\hline & Associate's degree & 58,52 & 14,24 & 57,89 & \\
\hline & $\begin{array}{l}\text { From Bachelor's } \\
\text { degree to } \\
\text { Doctorate }\end{array}$ & 58,91 & 11,58 & 57,89 & \\
\hline \multirow[t]{2}{*}{ Health-care worker } & Yes & 58,80 & 13,72 & 57,89 & ${ }^{b} 0,280$ \\
\hline & No & 62,00 & 15,49 & 63,16 & \\
\hline \multirow[t]{4}{*}{ Number of children } & Zero & 58,62 & 13,95 & 57,89 & ${ }^{a} 0,025 *$ \\
\hline & 1 child & 60,86 & 14,59 & 63,16 & \\
\hline & 2 children & 60,57 & 17,08 & 63,16 & \\
\hline & 3 and more & 64,76 & 15,80 & 63,16 & \\
\hline \multirow[t]{2}{*}{$\begin{array}{l}\text { Use of public } \\
\text { transportation }\end{array}$} & Yes & 60,77 & 13,78 & 63,16 & ${ }^{b} 0,595$ \\
\hline & No & 59,95 & 15,12 & 57,89 & \\
\hline \multirow{3}{*}{$\begin{array}{l}\text { Suspected COVID- } \\
19 \text { exposure }\end{array}$} & No & 60,24 & 14,77 & 57,89 & ${ }^{c} 0,531$ \\
\hline & Yes & 63,16 & 12,89 & 63,16 & \\
\hline & Not sure & 55,85 & 16,95 & 60,53 & \\
\hline Gestational age & $<14$ gw & 60,76 & 13,93 & 63,16 & ${ }^{a} 0,380$ \\
\hline
\end{tabular}




\begin{tabular}{|c|c|c|c|c|c|}
\hline & 14-28 gw & 59,14 & 14,23 & 57,89 & \\
\hline & $>28 \mathrm{gw}$ & 60,36 & 15,16 & 57,89 & \\
\hline \multirow{3}{*}{$\begin{array}{l}\text { How many people } \\
\text { do live in your } \\
\text { house? }\end{array}$} & 1-2 people & 58,59 & 13,63 & 57,89 & \multirow[t]{3}{*}{$0,011 *$} \\
\hline & 3-5 people & 61,91 & 15,06 & 63,16 & \\
\hline & $>6$ people & 57,06 & 18,38 & 57,89 & \\
\hline \multirow{3}{*}{$\begin{array}{l}\text { Routine prenatal } \\
\text { visits }\end{array}$} & Never & 57,69 & 15,87 & 57,89 & \multirow[t]{3}{*}{$0,001 * *$} \\
\hline & Irregular & 59,62 & 14,18 & 57,89 & \\
\hline & Regular & 64,43 & 14,94 & 68,42 & \\
\hline
\end{tabular}

${ }^{a}$ Oneway Anova test

${ }^{b}$ Student $t$ test

${ }^{c}$ Kruskal Wallis test ${ }^{*} p<0,05$

Table 7: Evaluation of COVID-19 Awareness Scores according to the risk factors of pregnant women

\begin{tabular}{|c|c|c|c|c|c|}
\hline & & \multicolumn{3}{|c|}{ COVID-19 Awareness Scores } & \multirow[b]{2}{*}{$\mathbf{p}$} \\
\hline & & Average & SD & Median & \\
\hline \multirow{2}{*}{$\begin{array}{l}\text { Diabetes } \\
\text { Mellitus }\end{array}$} & No & 60,20 & 14,76 & 57,89 & 0,571 \\
\hline & Yes & 58,22 & 16,81 & 60,53 & \\
\hline \multirow[t]{2}{*}{ Hypertension } & No & 60,30 & 14,65 & 57,89 & 0,312 \\
\hline & Yes & 53,07 & 20,38 & 57,89 & \\
\hline \multirow[t]{2}{*}{ Lung Diseases } & No & 60,24 & 15,01 & 57,89 & 0,364 \\
\hline & Yes & 58,27 & 10,90 & 57,89 & \\
\hline \multirow{2}{*}{$\begin{array}{l}\text { Cancer } \\
\text { Diseases }\end{array}$} & No & 60,14 & 14,77 & 57,89 & 0,699 \\
\hline & Yes & 60,15 & 19,66 & 63,16 & \\
\hline \multirow[t]{2}{*}{ Heart Diseases } & No & 53,13 & 12,88 & 52,63 & $0,016 *$ \\
\hline & Yes & 60,43 & 14,83 & 63,16 & \\
\hline \multirow[t]{2}{*}{ Liver Diseases } & No & 60,08 & 14,86 & 57,89 & 0,475 \\
\hline & Yes & 63,82 & 12,08 & 65,79 & \\
\hline \multirow[t]{2}{*}{ Renal Diseases } & No & 60,12 & 14,79 & 57,89 & 0,830 \\
\hline & Yes & 61,40 & 18,13 & 63,16 & \\
\hline \multirow{2}{*}{$\begin{array}{l}\text { Thyroid } \\
\text { Diseases }\end{array}$} & No & 59,95 & 14,77 & 57,89 & 0,094 \\
\hline & Yes & 64,74 & 15,75 & 68,42 & \\
\hline \multirow[t]{2}{*}{ Other Diseases } & No & 60,05 & 14,78 & 57,89 & 0,399 \\
\hline & Yes & 63,16 & 16,40 & 68,42 & \\
\hline \multirow[t]{2}{*}{ None } & No & 59,93 & 15,23 & 63,16 & 0,988 \\
\hline & Yes & 60,19 & 14,73 & 57,89 & \\
\hline
\end{tabular}

Table 8: Distribution of COVID-19 Anxiety Scores

COVID-19 Anxiety Scores 


\begin{tabular}{lc}
\hline Min-Max & $13,33-86,67$ \\
Avr \pm SD & $53,49 \pm 13,63$ \\
\hline Low Anxiety Levels & $60(11,4)$ \\
\hline Moderate Anxiety Levels & $348(66,2)$ \\
\hline High Anxiety Levels & $118(22,4)$ \\
\hline
\end{tabular}

Table 9: Evaluations based on COVID-19 Anxiety Scores

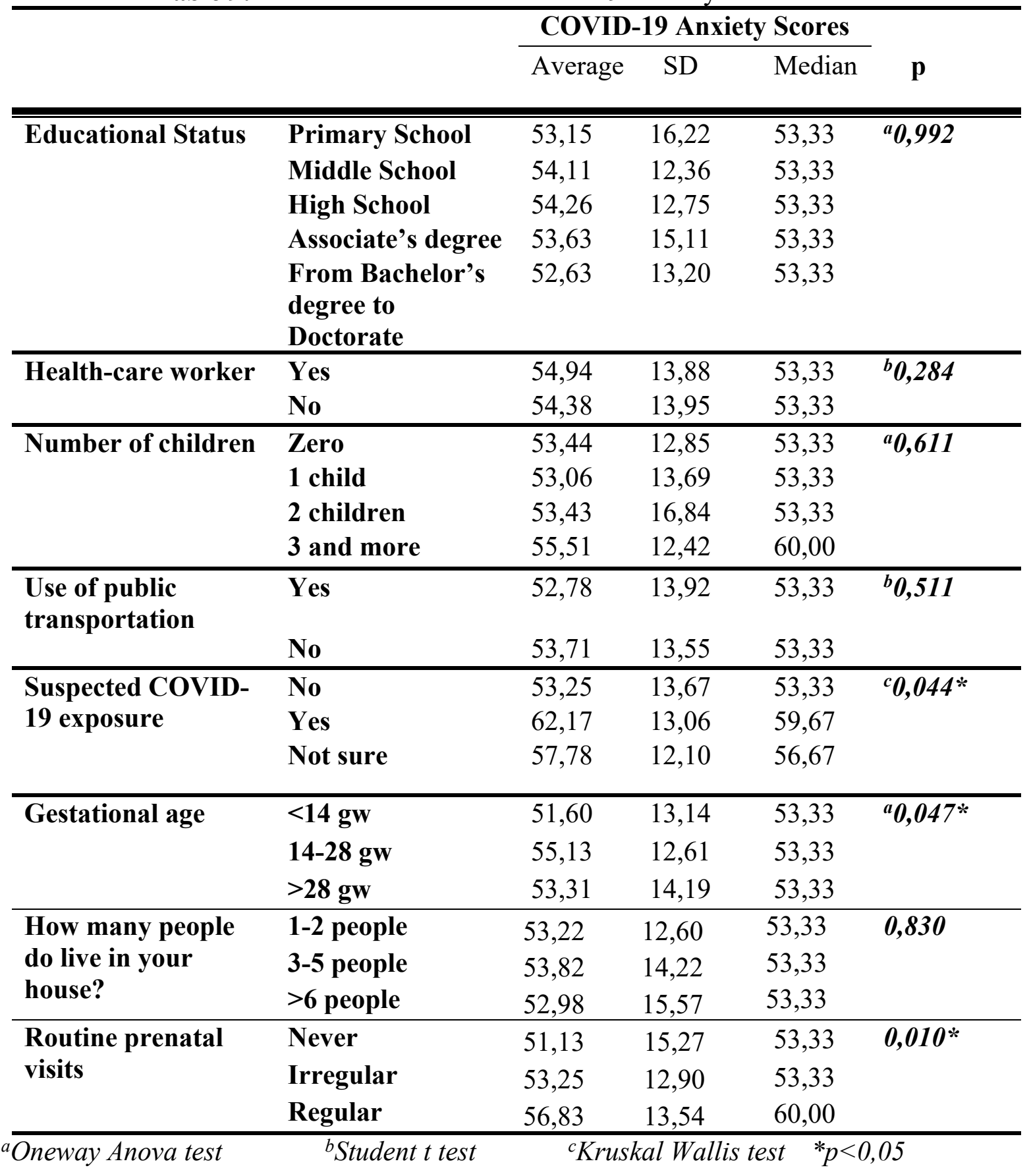


Table 10: Evaluation of COVID-19 Anxiety Scores according to the risk factors of pregnant women

\begin{tabular}{|c|c|c|c|c|c|}
\hline & & $\mathrm{COVl}$ & 9 Anxi & cores & \\
\hline & & Average & $\mathrm{SD}$ & Median & $\mathbf{p}$ \\
\hline Diabetes & No & 52,31 & 13,68 & 2 & $0,046 *$ \\
\hline Mellitus & Yes & 59,58 & 10,74 & 60,00 & \\
\hline Hypertension & No & 53,46 & 13,51 & 53,33 & 0,757 \\
\hline & Yes & 55,00 & 18,88 & 53,33 & \\
\hline Lung Diseases & No & 53,71 & 13,74 & 53,33 & 0,107 \\
\hline & Yes & 49,76 & 11,11 & 46,67 & \\
\hline Cancer & No & 53,47 & 13,63 & 53,33 & 0,484 \\
\hline & Yes & 55,24 & 14,25 & 60,00 & \\
\hline Heart Diseases & No & 53,48 & 13,71 & 53,33 & 0,640 \\
\hline & Yes & 53,97 & 11,72 & 60,00 & \\
\hline Liver Diseases & No & 53,55 & 13,63 & 53,33 & 0,456 \\
\hline & Yes & 50,00 & 14,25 & 53,33 & \\
\hline Renal Diseases & No & 53,46 & 13,66 & 53,33 & 0,607 \\
\hline & Yes & 56,66 & 11,74 & 53,33 & \\
\hline Thyroid & No & 53,32 & 13,54 & 53,33 & 0,101 \\
\hline Diseases & Yes & 58,00 & 15,46 & 60,00 & \\
\hline Other Diseases & No & 53,50 & 13,73 & 53,33 & 0,972 \\
\hline & Yes & 53,33 & 9,76 & 53,33 & \\
\hline None & No & 53,96 & 13,48 & 53,33 & 0,591 \\
\hline & Yes & 53,38 & 13,68 & 53,33 & \\
\hline
\end{tabular}


Figures

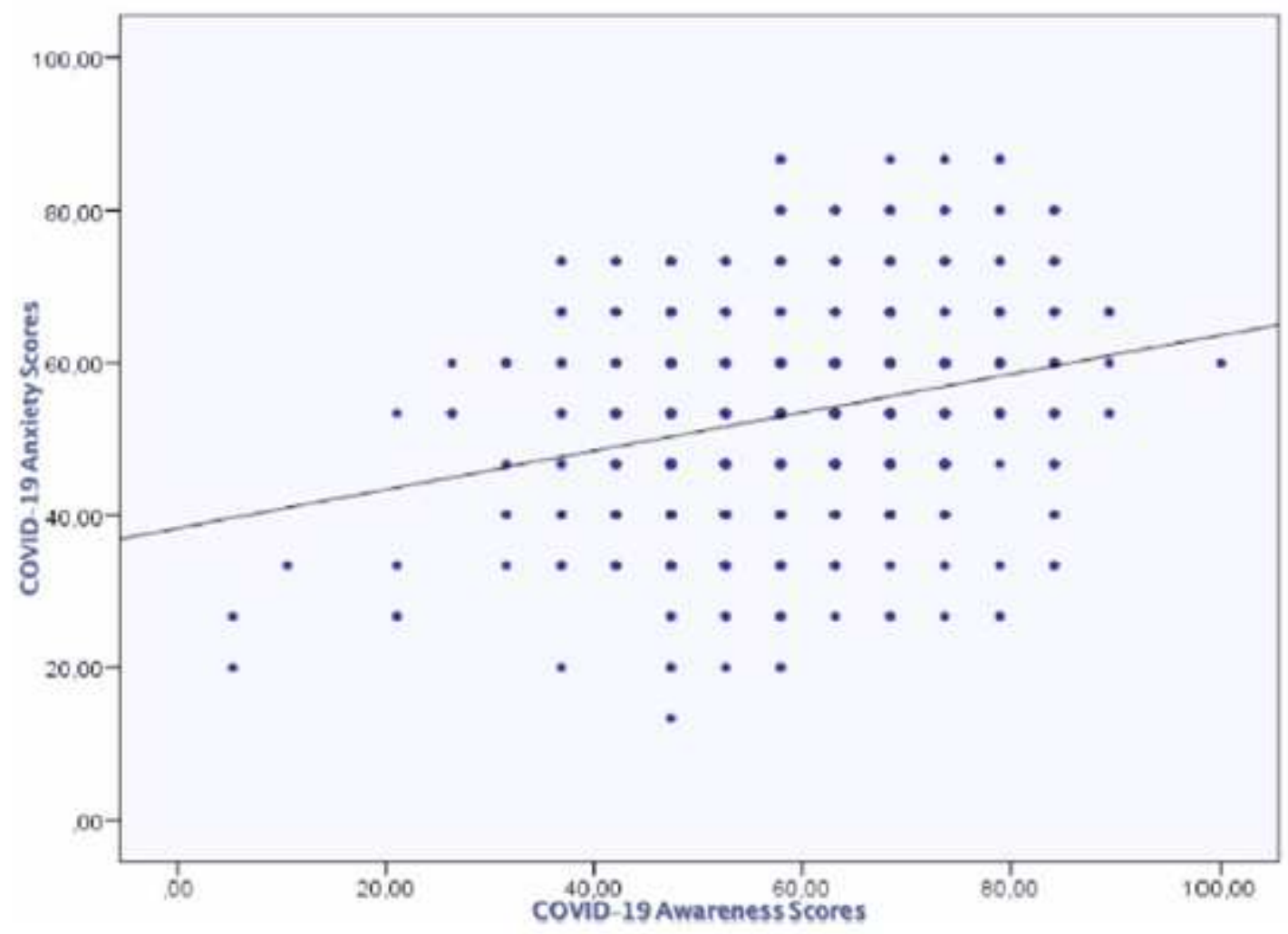

Figure 1

Relationship between COVID-19's anxiety scores and awareness scores on pregnant women

\section{Supplementary Files}

This is a list of supplementary files associated with this preprint. Click to download.

- COVID19questionnaire.docx 